\title{
Spreadsheet to Calculate the Economic Feasibility of Anaerobic Manure Digesters on Florida Dairy Farms ${ }^{1}$
}

\author{
Albert de Vries, Russ G. Giesy, Ann C. Wilkie, Roger A. Nordstedt ${ }^{2}$ \\ Building a renewable and sustainable energy \\ supply is one of the most important scientific \\ challenges of the 21 st century. One of the most \\ promising alternative energy sources is biomass, \\ which includes livestock manure, agricultural crops, \\ and organic residues. Florida's dairy farmers can \\ flushwater usage, extent of solids separation, and \\ other relevant parameters, in order to design an \\ appropriate digester for a given farm situation. Future \\ plans for herd expansion should also be considered in \\ sizing a digester so that adequate digester capacity is \\ available.
} provide a reliable supply of these materials and may earn extra income doing so. Methane, which can be produced from biomass through conversion in anaerobic digesters, is a versatile form of energy and can be used for all applications designed for natural gas. However, anaerobic digester technology requires a significant capital investment. Therefore, interested dairy farmers should first conduct a careful economic feasibility study.

The parameters of any waste management system are site-specific and may vary significantly from one dairy farm to the next. The bioenergy potential of the feedstock is an important parameter in sizing a digester and the economic feasibility. Therefore, it is important to characterize the wastewater and compile baseline data with regard to number of animals, degree of confinement and type of bedding, feed ration/dry matter intake, volume of
This fact sheet describes a spreadsheet that evaluates the economic feasibility of investment in anaerobic manure digesters on Florida dairy farms that use hydraulic flushing systems for manure management. The spreadsheet DIGESTER.XLS is available from the Florida Dairy Extension website at http://dairy.ifas.ufl.edu/tools. Comments provided in the spreadsheet explain the user-input and calculations when necessary. Realistic default values are given. Four alternative scenarios can be compared to two default scenarios, a fixed-film anaerobic digester and a covered lagoon digester.

Based on user-defined inputs and engineering constants, the spreadsheet first calculates the annual amount of methane $\left(\mathrm{CH}_{4}\right)$ produced by the digester. It also calculates the amount of electricity that can be generated from the methane as well as the amount of carbon dioxide $\left(\mathrm{CO}_{2}\right)$ reduction achieved.

1. This document is AN176, one of a series of the Department of Animal Sciences, Florida Cooperative Extension Service, Institute of Food and Agricultural Sciences, University of Florida. Original publication date September, 2006. Visit the EDIS Web Site at http://edis.ifas.ufl.edu.

2. Albert De Vries, UF/IFAS Department of Animal Sciences; Russ G. Giesy, UF/IFAS Extension Dairy Science; Ann C. Wilkie, UF/IFAS Department of Soil \& Water Science; Roger A. Nordstedt, UF/IFAS Department of Agricultural \& Biological Engineering; Cooperative Extension Service, UF/IFAS, Gainesville, FL 32611.

The Institute of Food and Agricultural Sciences (IFAS) is an Equal Opportunity Institution authorized to provide research, educational information and other services only to individuals and institutions that function with non-discrimination with respect to race, creed, color, religion, age, disability, sex, sexual orientation, marital status, national origin, political opinions or affiliations. U.S. Department of Agriculture, Cooperative Extension Service, University of Florida, IFAS, Florida A. \& M. University Cooperative Extension Program, and Boards of County Commissioners Cooperating. Larry Arrington, Dean 
The spreadsheet calculates the economic feasibility of methane when 1) converted to electricity to avoid electricity purchases or to sell to a utility company and when 2) sold as gas to a utility company. Investment evaluations consider the capital investment cost, cost share, income tax rate, discount rate, operating and maintenance cost, productive lifetime, and salvage value of the digester. Investment criteria are net present value, cost-benefit ratio, internal rate of return, payback period, and equivalent annual annuity.

Some additional benefits of anaerobic digesters have not been considered in the evaluation. For example, properly functioning anaerobic digesters reduce odor and may help the dairy farm meet future air quality regulations. The value of the $\mathrm{CO}_{2}$ reduction as carbon credits is calculated, but it is not considered in the investment evaluation.

\section{References}

Giesy, Russ, Ann Wilkie, Albert De Vries, and Roger Nordstedt. 2005. Economic feasibility of anaerobic digestion to produce electricity on Florida dairy farms.Document AN159. Available at http://edis.ifas.ufl.edu/AN159

U.S. Environmental Protection Agency. AgSTAR Program, Available at http://www.epa.gov/agstar/

Wilkie, A.C. 2005.. Anaerobic Digestion of Dairy Manure: Design and Process Considerations. In: Dairy Manure Management: Treatment, Handling, and Community Relations. NRAES-176, p.301-312. Natural Resource, Agriculture, and Engineering Service, Cornell University, Ithaca, NY, 2005. Available at http://dairy.ifas.ufl.edu/2005/NRAES-176-

March2005-p301-312.pdf 